\title{
The Effect of Initial Cooling Temperature on Deformation of U75V Heavy Rail after Cooling
}

\author{
Mingxin Gao ${ }^{1, a}$, Hao Jia ${ }^{2, b}$, Juanjuan Jiang ${ }^{2, b}$, Peilong Wang ${ }^{2, b}$, \\ Hua Song ${ }^{2, b}$, Siyu Yuan ${ }^{3, c}$ and Zhongqiang Wang ${ }^{3, c}$ \\ ${ }^{1}$ Heavy Equipment Manufacturing Factory of China First Heavy Industries, China \\ ${ }^{2}$ University of Science and Technology Liaoning, Anshan, Liaoning114051, China \\ ${ }^{3}$ Anshan Iron \& Steel Co; Ltd., Anshan, Liaoning 114021, China \\ agaoming31@163.com, bsonghua88@126.com, 'wzhq@163.com
}

Keywords: initial temperature, heat-stress couple, cooling bed

\begin{abstract}
The initial cooling temperature has important effect on the bending change and section size of rolled heavy rail, when rolled heavy rail is on the cooling bed for natural cooling. In the paper, the heat-stress couple method is adopted to carry on numerical simulation to cooling process of $60 \mathrm{~kg} / \mathrm{m} \mathrm{U75V}$ heavy rail, and we has obtained the bending change value and section size of rolled heavy rail in different initial cooling temperature. The study is of great reference value on the design of cooling bed which is for hundred-meter high speed heavy rail and the formulation of cooling technological parameters.
\end{abstract}

\section{Introduction}

When rolled heavy rail is on the cooling bed for natural cooling, its bending deformation caused by solid phase changing and the section size contraction deformation occurs, there are many factors affecting cooling after deformation of heavy rail, such as the initial cooling temperature, environment temperature and cooling rate ${ }^{[1]}$. Reference [1] briefly analyses the impact of the initial temperature on the bending of cold heavy rail, Reference [2,3] study on bending deformation of heavy rail being cooling, and the information that initial cooling temperature effects on rolled heavy rail section size is not reported until now. In the paper, the heat-stress couple method is adopted to carry on numerical simulation to cooling process of $60 \mathrm{~kg} / \mathrm{m}$ U75V heavy rail, and we has obtained the bending change value and section size of rolled heavy rail in different initial cooling temperature. The study is of great reference value on the design of cooling bed which is for hundred-meter high speed heavy rail and the formulation of cooling technological parameters.

\section{The establishment of heavy rail cooling FEM model}

Establishment of geometric model. The section shape and size of $60 \mathrm{~kg} / \mathrm{m}$ heavy rail is shown in Figure 1. Considering the complex heavy rail section sizes and the computing time, the fillet of $2 \mathrm{~mm}$ and $3 \mathrm{~mm}$ radius have been simplified in this paper, and the model of heavy rail has been taken as length of $2000 \mathrm{~mm}$. The SOLID5 unit which has the function of limited coupling between temperature and structure field is adopted in meshing, rail model was classified a total of 44,000 units (dividing 250 equal parts along the length direction), 57,479 node, it is shown in Figure 2. 


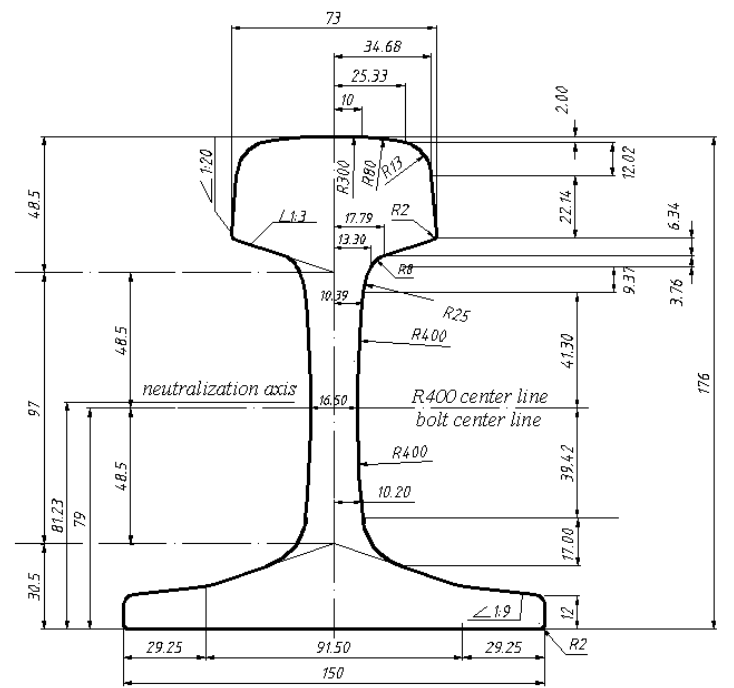

Fig. $1.60 \mathrm{~kg} / \mathrm{m}$-section shapes of heavy rail dimensions

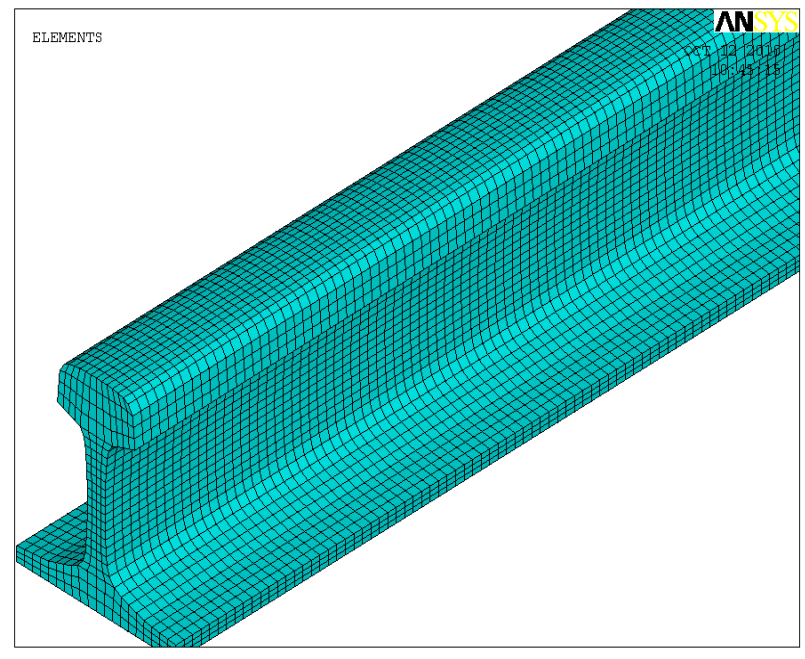

Fig. 2. Heavy rail meshing

Thermal physical parameters of heavy rail materials. Flashline TM-5000 Thermal Properties Analyze produced by United States Anter Company is applied to measuring U75V heavy rail specific heat $\mathrm{c}$ and the coefficient of thermal conductivity $\lambda$, and it is shown in Figures 3 and 4, respectively. Enthalpy $H$ changes with temperature curve is shown in Figure $5^{[4]}$, other thermo physical parameters are shown in table 1.

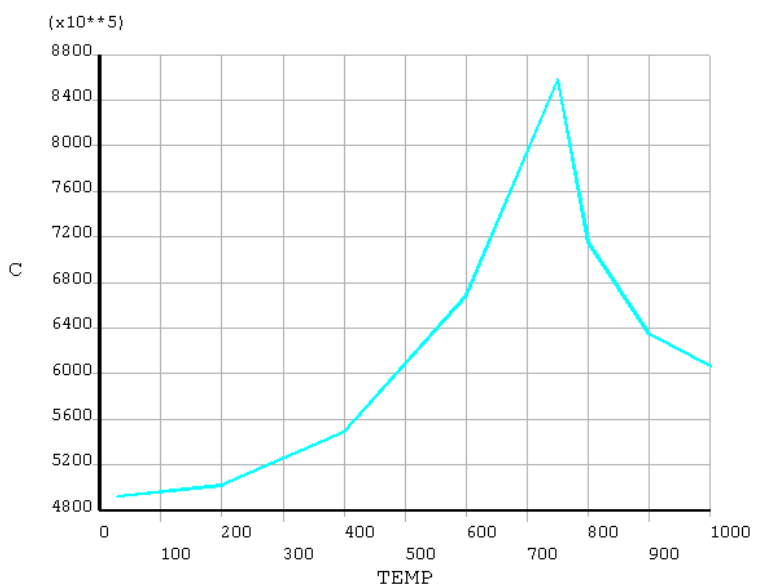

Fig. 3. Specific heat $c$ changes with temperature curve

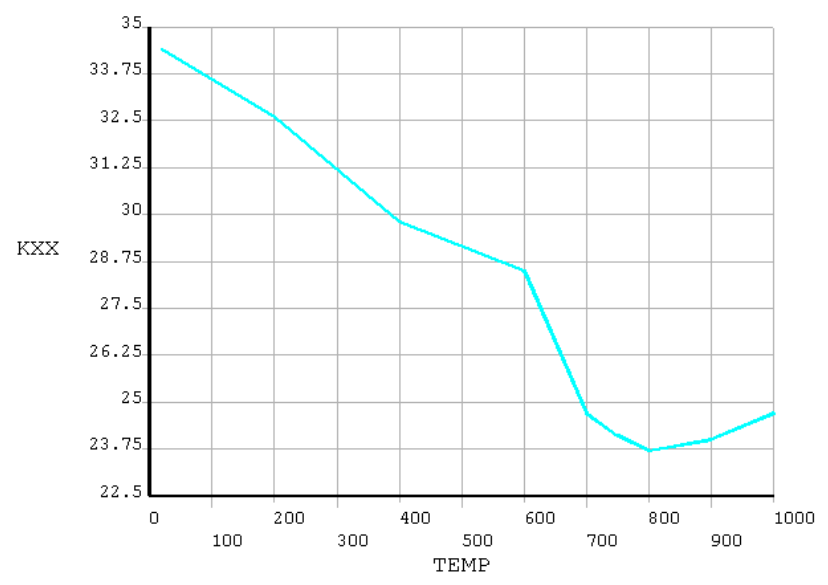

Fig. 4. Coefficient of thermal conductivity $\lambda$ changes with temperature curve

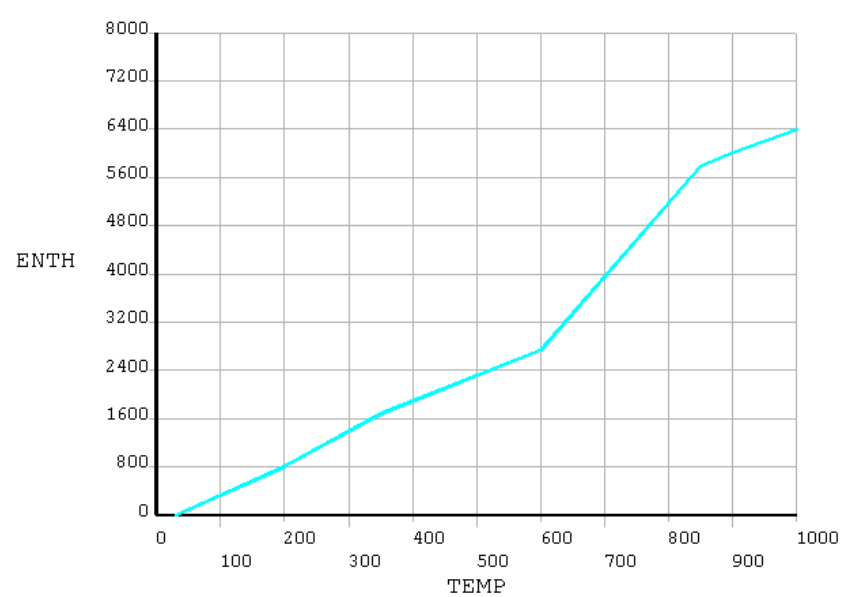

Fig. 5. Enthalpy $H$ changes with temperature curve 
Table 1 U75 thermal physical parameters

\begin{tabular}{c|cccc}
\hline Temperature $\left({ }^{\circ} \mathrm{C}\right)$ & Density $\rho\left(\mathrm{kg} / \mathrm{m}^{3}\right)$ & $\begin{array}{c}\text { Linear thermal } \\
\text { expansion } \\
\text { coefficient } \times 10^{-5}\end{array}$ & $\begin{array}{c}\text { Elastic } \\
\text { modulus } \\
E \times 10^{5}(\mathrm{Mpa})\end{array}$ & $\mu$ \\
\hline 30 & 7760 & 0.067 & 2.09 & 0.3 \\
200 & 7760 & 0.179 & 1.09 & 0.26 \\
300 & 7760 & 0.321 & 1.89 & 0.23 \\
350 & 7760 & & & \\
400 & 7760 & 0.49 & 1.68 & 0.13 \\
600 & 7760 & 0.831 & & \\
700 & 7760 & 1.00 & & \\
750 & 7760 & & 1.329 & 0.12 \\
800 & 7760 & 1.12 & 1.09 & 0.12 \\
850 & 7760 & & 0.975 & 0.12 \\
\hline 900 & 7760 & 1.30 & & \\
1000 & 7760 & 1.51 & & \\
\hline
\end{tabular}

Determination of cooling boundary conditions. To calculate the heat-transfer coefficients during the natural cooling process of heavy rail on the cooling bed, the method of experience formula is adopted in this paper, as follows ${ }^{[5]}$ :

$$
H=2.6\left(T_{w}-T_{c}\right)^{0.25}+4.84 \times 10^{-8}\left(T_{w}^{2}+T_{c}^{2}\right)\left(T_{w}+T_{c}\right)
$$

In which: $T_{w}$ temperature of work piece;

$T_{c} \longrightarrow$ temperature of environment, $T_{c}=30^{\circ} \mathrm{C}$.

\section{Initial cooling temperature effecting on bending and section sizes of cold heavy rail}

Thermo-mechanical coupling module of software Ansys is applied to numerical simulation on

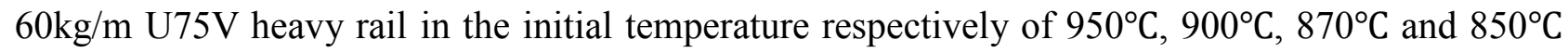
during the cooling process, and it is found that the bending and the section size change of cooling after heavy rail in different initial cooling temperature.

Effects of initial cooling temperature on bending. The simulation result was dealt with by Ansys and Microsoft Excel 2003, it's shown in table 2.

Table 2 The bending curvature radius of cold heavy rail in different initial temperature

\begin{tabular}{c|cccc}
\hline Initial temperature & $950^{\circ} \mathrm{C}$ & $900^{\circ} \mathrm{C}$ & $870^{\circ} \mathrm{C}$ & $850^{\circ} \mathrm{C}$ \\
\hline $\begin{array}{c}\text { Curvimeter } \\
\text { radius }(\mathrm{mm})\end{array}$ & 1909892 & 2041941 & 2256456 & 2301894 \\
\hline
\end{tabular}


From table 2, the higher initial temperature cooling after rolling is, the smaller bending curvature radius value of cold rail is. In opposition, the lower initial temperature is, the greater bending curvature radius value of cold rail is. In other words, appropriate reducing of initial cooling temperature can reduce the bending of cold rail. The middle line bending curves of cold rail bottom in different initial temperatures are shown in Figure 6.

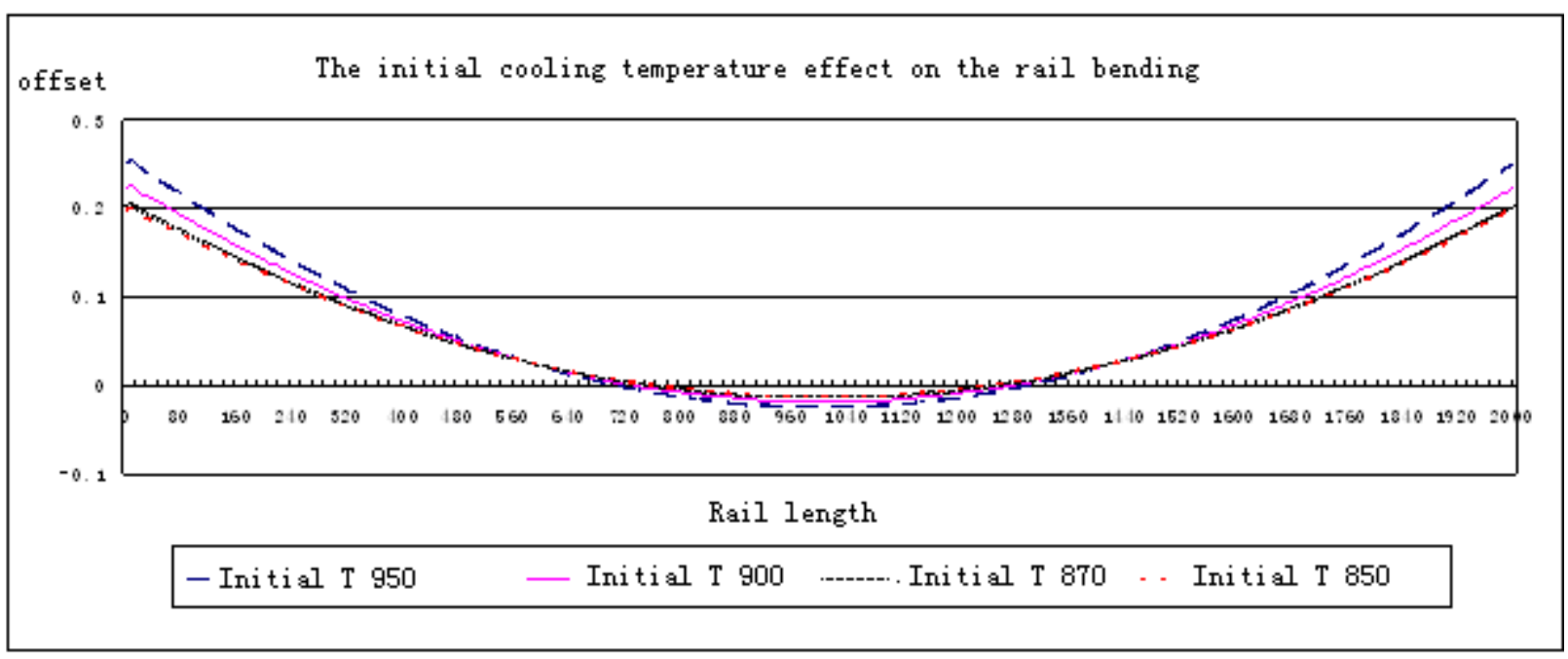

Fig. 6. The relationship of initial cooling temperature and cold rail bending curves

Effect of initial temperature on the section size. To study the section size change of cooled rail. the change of rail's dimensions in the height direction( including: height of the rail $H$, height of the railhead $H_{l}$, height of the split $H_{2}$, height of the bottom $H_{3}$ ) and in the width direction( including: width of the top of railhead $B_{1}$, width of the middle of railhead $B_{2}$, width of the bottom of railhead $B_{3}$, width of the split $B_{4}$,width of the bottom $B_{5}$ ) are analyzed,and geometric size measuring points in rail section are shown in Figure 7. Table 3 and table 4 indicates the change of rail dimension in the height and width in different initial temperatures after cooling.

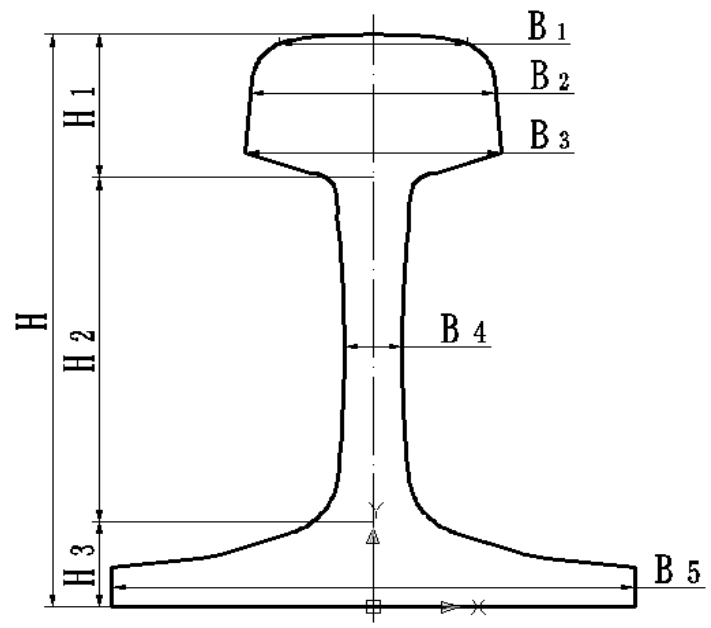

Fig. 7. Measuring points in rail section

As is shown in table 3, after cooling, the height of rail-head's contraction rate is the most, the height of split's the second, the height of bottom's the minimum. As the initial temperature increases before cooling, the contraction and contraction rates of cooled rail along height direction increased with it, but the increment is little. The contraction and contraction rates of rail height, from $850^{\circ} \mathrm{C}, 0.1313 \mathrm{~mm}$ and $0.7460 \%$, respectively increase to $950^{\circ} \mathrm{C}, 0.1532 \mathrm{~mm}$ and $0.8704 \%$. The contraction increases only $0.0219 \mathrm{~mm}$, and contraction rates increases $0.1234 \%$. 
From table 4 , the cooled rail top width $B_{1}$, the middle width $B_{2}$ and the lower part width $B_{3}$ contraction rate got the most, and basically the same; it was more than the contraction of rail split width $B_{4}$. The bottom width $B_{5}$ has the minimum contraction rate. As the temperature before cooling increased, the contraction and contraction rates increased along rail width direction with it, but the incremental value is little. The $B_{1}$ contraction rate along the top width of rail head direction after cooling, from $850^{\circ} \mathrm{C}, 0.774 \%$ o respectively increases to $950^{\circ} \mathrm{C}, 0.907 \%$, and contraction rate increases $0.123 \%$.

As is known from table 3 and table 4, in the same initial cooling temperature, the contraction rates of cooled rail in the height and width direction are basically the same, and the contraction deformation of heavy rail is equality.

Table 3 Different initial temperatures cooling after the high rail changes

\begin{tabular}{|c|c|c|c|c|c|}
\hline & $\begin{array}{c}\text { Initial } \\
\text { temperature }\end{array}$ & $\begin{array}{c}\text { height of } \\
\text { rail } H_{1}\end{array}$ & $\begin{array}{c}\text { height of split } \\
\mathrm{H}_{2}\end{array}$ & $\begin{array}{c}\text { height of bottom } \\
\mathrm{H}_{3}\end{array}$ & $\begin{array}{c}\text { Total height } \\
H\end{array}$ \\
\hline $\begin{array}{c}\text { The original size } \\
\text { of heavy rail }\end{array}$ & & 44.0211 & 105.6507 & 26.3250 & 175.9967 \\
\hline \multirow{4}{*}{$\begin{array}{c}\text { Cooling after } \\
\text { heavy rail } \\
\text { dimensions }(\mathrm{mm})\end{array}$} & $950^{\circ} \mathrm{C}$ & 43.9810 & 105.5599 & 26.3026 & 175.8435 \\
\hline & $900^{\circ} \mathrm{C}$ & 43.9840 & 105.5665 & 26.3042 & 175.8546 \\
\hline & $870^{\circ} \mathrm{C}$ & 43.9866 & 105.5723 & 26.3056 & 175.8646 \\
\hline & $850^{\circ} \mathrm{C}$ & 43.9869 & 105.5728 & 26.3058 & 175.8654 \\
\hline \multirow{4}{*}{$\begin{array}{c}\text { Height } \\
\text { contraction after } \\
\text { cooling }(\mathrm{mm})\end{array}$} & $950^{\circ} \mathrm{C}$ & 0.0401 & 0.0907 & 0.0224 & 0.1532 \\
\hline & $900^{\circ} \mathrm{C}$ & 0.0371 & 0.0842 & 0.0208 & 0.1421 \\
\hline & $870^{\circ} \mathrm{C}$ & 0.0345 & 0.0784 & 0.0193 & 0.1322 \\
\hline & $850^{\circ} \mathrm{C}$ & 0.0342 & 0.0779 & 0.0192 & 0.1313 \\
\hline \multirow{4}{*}{$\begin{array}{l}\text { Height } \\
\text { contraction rate } \\
\text { after cooling }\end{array}$} & $950^{\circ} \mathrm{C}$ & $0.9109 \%$ & $0.8589 \%$ & $0.8491 \%$ & $0.8704 \%$ \\
\hline & $900^{\circ} \mathrm{C}$ & $0.8248 \%$ & $0.7971 \%$ & $0.7886 \%$ & $0.8072 \%$ \\
\hline & $870^{\circ} \mathrm{C}$ & $0.7826 \%$ & $0.7418 \%$ & $0.7343 \%$ o & $0.7509 \%$ \\
\hline & $850^{\circ} \mathrm{C}$ & $0.7769 \%$ & $0.7371 \%$ & 0.7299\%о & $0.7460 \%$ \\
\hline
\end{tabular}

Table 4 Different initial temperatures cooled rail width variation

\begin{tabular}{|c|c|c|c|c|c|c|}
\hline Measure location & $\begin{array}{c}\text { Initial } \\
\text { temperature }\end{array}$ & $\begin{array}{l}\text { width of } \\
\text { railhead } \\
\text { top } B_{1}\end{array}$ & $\begin{array}{l}\text { width of } \\
\text { railhead } \\
\text { middle } B_{2}\end{array}$ & $\begin{array}{c}\text { width of } \\
\text { railhead } \\
\text { bottom } B_{3}\end{array}$ & $\begin{array}{l}\text { width of } \\
\text { split } B_{4}\end{array}$ & $\begin{array}{l}\text { width of } \\
\text { bottom } B_{5}\end{array}$ \\
\hline $\begin{array}{l}\text { Heavy rail to the } \\
\text { original size }(\mathrm{mm})\end{array}$ & & 60.1480 & 70.2914 & 73 & 16.5461 & 150 \\
\hline \multirow{4}{*}{$\begin{array}{c}\text { Cooling after } \\
\text { heavy rail } \\
\text { dimensions }(\mathrm{mm})\end{array}$} & $950^{\circ} \mathrm{C}$ & 60.0934 & 70.2277 & 72.9338 & 16.5320 & 149.8770 \\
\hline & $900^{\circ} \mathrm{C}$ & 60.0975 & 70.2324 & 72.9387 & 16.5330 & 149.8856 \\
\hline & $870^{\circ} \mathrm{C}$ & 60.1011 & 70.2366 & 72.9431 & 16.5339 & 149.8933 \\
\hline & $850^{\circ} \mathrm{C}$ & 60.1014 & 70.2370 & 72.9435 & 16.5340 & 149.8939 \\
\hline \multirow{4}{*}{$\begin{array}{c}\text { Width } \\
\text { contraction after } \\
\text { cooling }(\mathrm{mm})\end{array}$} & $950^{\circ} \mathrm{C}$ & 0.0546 & 0.0637 & 0.0662 & 0.0141 & 0.1230 \\
\hline & $900^{\circ} \mathrm{C}$ & 0.0505 & 0.0590 & 0.0613 & 0.0131 & 0.1144 \\
\hline & $870^{\circ} \mathrm{C}$ & 0.0469 & 0.0548 & 0.0569 & 0.0122 & 0.1066 \\
\hline & $850^{\circ} \mathrm{C}$ & 0.0466 & 0.0544 & 0.0565 & 0.0121 & 0.1061 \\
\hline \multirow{4}{*}{$\begin{array}{l}\text { Width } \\
\text { contraction after } \\
\text { cooling }\end{array}$} & $950^{\circ} \mathrm{C}$ & $0.9070 \%$ & $0.9064 \%$ & $0.9075 \%$ & $0.8495 \%$ o & $0.8197 \%$ \\
\hline & $900^{\circ} \mathrm{C}$ & $0.8394 \%$ & $0.8388 \%$ & $0.8398 \%$ & $0.7888 \%$ & $0.7626 \%$ \\
\hline & $870^{\circ} \mathrm{C}$ & $0.7795 \%$ & $0.7790 \%$ & $0.7799 \%$ & $0.7343 \%$ о & $0.7110 \%$ \\
\hline & $850^{\circ} \mathrm{C}$ & $0.7740 \%$ & $0.7735 \%$ & $0.7744 \%$ & $0.7298 \%$ & $0.7071 \%$ \\
\hline
\end{tabular}




\section{Summary}

1. With the increasing of initial temperature, the bending curvature radius of cold rail is reducing, its curvature increased, and the cooled rail bending reduced through appropriate reducing the initial cooling temperature.

2. After cooling process, the height of rail-head's contraction rate is the most, the height of split's the second, and the height of bottom's the minimum. As the initial temperature increases before cooling, the contraction and contraction rates along cooled rail height direction increased with it, but the increment is little.

3. After cooling, the top of rail head width $B_{l}$, the middle width $B_{2}$ and the lower part of rail head width $B_{3}$ contraction is the maximum, and basically the same, the contraction of rail split width $B_{4}$ is less than that, the contraction of bottom width $B_{5}$ is the minimum. As the initial temperature before the cooling increased, the width dimension contraction and contraction rate of cooled rail increased with it.

\section{Acknowledgement}

Supported by National Science Foundation of China, ID5107488.

\section{References}

[1] Hua Guo, Deng Yong. Simulation analysis of rail's bending formation during cooling process. 2006 Conference on theory and technology of plastic processing in China, 2006, Qingdao.

[2] Li Ge, Jia Baohua, Jiang Xu. Finite element analysis of bending deformation in the cooling process before straightened of hundred-metre U75V heavy rail. Special steel, 2010, 6, 31(3): 14-16.

[3] J Basu, S L Srimani, D S Gupta. Rail behavior during cooling after hot rolling. The Journal of Strain Analysis for Engineering Design. 2004, Vol.39, No. 1: p.15-24.

[4] Xu Zhuyao. Thermodynamics of metallic material. Beijing: Science press, 1981.7.

[5] Zhou Jianhua, Lin Gang, Wu Di, Zhao Xianming. Finite element simulation and analysis of the temperature field during the cooling of $60 \mathrm{~kg} / \mathrm{m}$ heavy rail. Journal of iron and steel research.2007, Vol.19, No.11: 29-32. 